\title{
PENGEMBANGAN VIDEO PEMBELAJARAN TEKNIK DASAR BERMAIN SEPAKBOLA MENGGUNAKAN KUN PADA SISWA SEKOLAH SEPAK BOLA (SSB) PORTIS SAENTIS
}

\author{
Hanafi Hasibuan \\ SSB Portis Saentis, Percut Sei Tuan, Deli Serdang, Sumatera Utara \\ unimedhevi@yahoo.com
}

\begin{abstract}
Abstrak: Tujuan penelitian ini adalah untuk mengembangkan media pembelajaran teknik dasar bermain sepakbola menggunaan kun, agar layak digunakan di sekolah serta mengetahui efektifitas hasil latihan siswa dengan menggunakan media pembelajaran teknik dasar bermain sepakbola menggunaan kun. Metode penelitian ini adalah metode penelitian dan pengembangan. Penelitian ini merupakan penelitian pengembangan yang bertujuan menghasilkan produk berupa video pembelajaran menggiring dan mengumpan bola pada teknik dasar sepakbola dengan menggunakan kun. Hasil penelitian menunjukkan bahwa: (1) siswa setelah mengikuti proses pembelajaran menggunakan produk pengembangan media pembelajaran dalam bentuk video pembelajaran teknik dasar menggiring dan mengumpan pada permainan sepakbola meningkat dibandingkan sebelum mengikuti pembelajaran menggunakan media pembelajaran dalam bentuk video pembelajaran teknik dasar menggiring dan mengumpan pada permainan sepakbola. (2)Video pembelajaran teknik dasar menggiring dan mengumpan pada permainan sepakbola melalui pembelajaran menggunaan kun layak digunakan pada siswa SSB PORTIS Saentis. Hasil latihan siswa melalui penggunaan video pembelajaran lebih efektif dibandingkan dengan hasil latihan siswa sebelum menggunakan video pembelajaran pada siswa SSB PORTIS Saentis.
\end{abstract}

Kata Kunci: video pembelajaran, kun, teknik dasar permainan sepak bola

Abstract: The purpose of this research is to develop learning media of basic technique of playing football using kun, to be feasible to be used in school and to know the effectiveness of student training result by using learning media of basic technique of playing football using kun. This research method is research and development method. This research is a development research that aims to produce a product in the form of learning videos leads and mengumpan ball on football basic techniques using kun. The results showed that: (1) the students after following the learning process using learning media development product in the form of learning video basic technique leads and feeds on the game of football increased than before following the learning using learning media in the form of learning video basic technique lead and feed on the game of football. (2) Basic instructional video learning videos leads and feeds on the game of soccer through learning to use the proper use of kun on SSTER PORTIS Saentis students. The results of the student exercises through the use of learning videos are more effective than the results of student exercises before using video learning on SSB students PORTIS Saentis.

Keywords: learning video, kun, basic soccer game techniques

\section{PENDAHULUAN}

Pendidikan jasmani olahraga dan kesehatan merupakan proses pendidikan yang memanfaatkan aktivitas jasmani untuk menghasilkan perubahan holistik dalam kualitas individu, baik dalam hal fisik, mental, serta emosional. Pendidikan jasmani olahraga dan kesehatan memperlakukan anak sebagai sebuah kesatuan utuh, mahkluk total, daripada hanya menganggapnya sebagai seseorang yang terpisah kualitas fisik dan mentalnya. Aktivitas jasmani dapat berupa permainan atau olahraga yang terpilih, kegiatan itu tidak hanya sekedar kegiatan biasa atau asal-asalan dan bukan hanya sekedar gerak badan yang tidak bermakna.

Tujuan yang ingin dicapai pada pendidikan jasmani olahraga dan kesehatan meliputi meliputi perkembangan kognitif, afektif dan psikomotor. Agar tujuan pendidikan jasmani olahraga dan kesehatan tersebut dapat benar-benar tercapai dengan baik, maka perlu peninjauan yang lebih mendalam lagi tentang 
konsep pendidikan jasmani olahraga dan kesehatan tersebut. Untuk itu maka mutu pendidikan jasmani olahraga dan kesehatan baik dari segi materi dan penyampaian, bahan ajar, pendidik, sarana prasarana dan peserta didik perlu dikaji lebih mendalam lagi.

Peningkatan mutu pendidikan jasmani olahraga dan kesehatan salah satunya dapat dilakukan dengan menerapkan pembelajaran teknik dasar sepak bola pada siswa SSB. Bebarapa teknik dasar sepak bola seperti menggiring, menendang, mengumpan, melempar bola dan lain-lain. Teknik-teknik dasar tersebut harusnya dikuasai siswa SSB. Ada pun pengertian dari teknik menggiring itu sendiri adalah penguasaan bola dengan kaki saat kita bergerak dilapangan. Pengertian dari teknik dasar mengumpan adalah seni memindahkan momentum bola dari satu pemain ke pemain lain (Danny, 2007:19).

Berdasarkan hasil analisis kebutuhan yang peneliti laksanakan pada SSB Portis Saentis Kecamatan Percut Sei Tuan Kabupaten Deli Serdang Tahun 2015 dengan menggunakan metode wawancara dan observasi, ternyata selama ini pembelajaran teknik menggiring dan mengumpan bola yang dilaksanakan kurang bervariasi dan masih rendahnya tingkat penguasaan teknik menggiring dan mengumpan bola pada siswa SSB Portis Saentis Kecamatan Percut Sei Tuan Kabupaten Deli Serdang Tahun 2015.

Pembelajaran menggiring dan mengumpan sudah diberikan namun masih banyak siswa belum bisa melakukan teknik menggiring dengan baik, selain itu kurangnya motivasi siswa ketika pembelajaran menggiring dan mengumpan bola karena kurangnya variasi latihan menggiring dan mengumpan bola yang menyenangkan. Berdasarkan hasil analisis kebutuhan tersebut, meneliti merasa perlu diadakan pembelajaran menggiring dan mengumpan bola dengan menggunakan media audio visual (video pembelajaran).

Banyak jenis olahraga yang dipakai dalam alat untuk menyampaikan pendidikan jasmani olahraga dan kesehatan. Salah satunya melalui olahraga permainan seperti sepak bola. Olahraga yang paling popular di dunia ini menjadi salah satu alat bantu dalam menyampaikan pendidikan jasmani olahraga dan kesehatan, seiring dengan perkembangan ilmu pengetahuan dan teknologi yang semakin pesat.
Disamping itu teknologi juga berpengaruh sangat besar bagi perkembangan pemainan, dimana permainan ini tidak memerlukan suatu aktifitas gerak yang aktif. Misalnya game online dan game komputer dan juga play station, dimana cara memainkan permainan ini hanya dengan duduk dan melihat monitor atau layar televisi tanpa melakukan aktivitas gerak yang berarti.

Hal ini akan menjadikan anak malas bergerak dan pada akhirnya akan menurunkan kesegaran jasmani mereka. Permainan sepak bola umumnya dilakukan dengan menggunakan prasarana lapangan, ukuran lapangan sepak bola yang standar adalah cukup luas. Untuk dapat bermain sepakbola di sekolah, dapat digunakan prasarana lapangan yang minimal bahkan di halaman sekolah. Agar proses pembelajaran dapat berlangsung dengan baik pada lapangan yang sempit, maka perlu dilakukan variasi dalam pelaksanaannya.

Variasi dalam pembelajaran adalah perubahan proses kegiatan yang bertujuan untuk meningkatkan motivasi belajar peserta didik, serta mengurangi kejenuhan dan kebosanan. Untuk mengatasi kebosanan siswa tersebut perlu adanya variasi, dalam keterampilan mengadakan variasi dalam proses belajar mengajar ada tiga aspek, yaitu : (1). variasi dalam gaya mengajar yang meliputi variasi suara, pemusatan perhatian, kesenyapan, pergantian posisi pelatih, kontak pandang serta gerakan badan dan mimik. (2). variasi pola interaksi dan kegiatan, (3). variasi penggunaan alat bantu pengajaran yang meliputi alat/bahan yang dapat didengar, dilihat, dan dimanipulasi, seperti penggunaan video pembelajaran (Mulyasa, 2010: 78).

Media pembelajaran yang akan dikembangkan dalam penelitian ini adalah berupa video pembelajaran teknik dasar permainan sepak bola yaitu menggiring dan mengumpan melalui variasi pembelajaran menggunakan kun sesuai peraturan yang digunakan dalam proses pembelajaran penjas. Ketertarikan penulis untuk melakukan penelitian ini berawal dari pengamatan penulis ketika melihat pembelajaran penjas yang dilakukan pelatih di SSB yang terlalu menonton dan jarang sekali memberikan materi pembelajaran dengan mengoptimalkan peranan media pembelajaran berbentuk audio visual. Kondisi ini memberikan gagasan dan ide dasar bagi penulis untuk menciptakan variasi pembelajaran pada salah satu jenis olahraga 
permainan yaitu olahraga sepak bola dengan memasukkan teknik dasar permainan tersebut kedalam bentuk video pembelajaran.

Luthan (2000:15) menyatakan bahwa pendidikan jasmani olahraga dan kesehatan merupakan proses pendidikan melalui aktivitas jasmani. Tujuan umum pendidikan jasmani olahraga dan kesehatan juga selaras dengan tujuan umum pendidikan. Tujuan belajar adalah menghasilkan perubahan perilaku yang melekat. Proses belajar dalam pendidikan jasmani olahraga dan kesehatan juga bertujuan untuk menimbulkan perubahan perilaku. Pendidikan jasmani olahraga dan kesehatan merupakan interaksi antara peserta didik dengan lingkungan secara sistematis untuk membentuk manusia seutuhnya.

Teknik dasar bermain sepak bola menurut (Soekatamsi, 1984:24) adalah semua gerakangerakan tanpa bola dengan gerakan-gerakan dengan bola yang diperlukan dalam bermain sepak bola, jadi teknik dasar bermain sepak bola adalah merupakan kemampuan untuk melakukan gerakan-gerakan atau mengerjakan sesuatu yang terlepas sama sekali dari permainan sepak bola yang professional harus menguasai teknik dasar bermain sepak bola terlebih dahulu sebelum bermain dalam permainan sepak bola.

Beberapa teknik dasar yang perlu dimiliki pemain sepakbola adalah (1).menggiring (dribbling), (2). mengoper/mengumpan (passing), (3) menghentikan atau mengontrol (stoping), (4) menyundul bola ( heading ), (5) merampas bola (tacling), (6).lemparan ke dalam (trow - in) dan (7) teknik menjaga gawang (goal keeping).

Pada dasarnya menggiring bola adalah menendang bola dengan terputus- putus atau pelan-pelan, oleh karena itu kaki yang dipergunakan dalam menggiring bola sama dengan kaki yang di gunakan untuk menendang bola. Menggiring bola bertujuan untuk mendekati jarak sasaran, melewati lawan dan menghambat permainan. (Sucipto, 2000:32)

Teknik menggiring bola yang baik dan benar akan memberikan kesan tersendiri bagi para penonton, menggiring bola menuntut keseimbangan yang baik, penguasaan yang luar biasa baik dan kepercayaan yang besar. Buatlah bola tetap berada di bawah kaki anda karena anda bisa lari mendahuluhi bola tersebut. Anda bisa menggunakan punggung kaki anda,dan kaki bagian luar dan dalam untuk menggerakan bola ke depan dan ke samping. Menggiring bola adalah suatu gerakan yang beresiko tinggi dan bahkan para pemain terbaik pun kadang terpaksa menyerahkan bola (Clive, 2002:27).

Dribbling adalah ketrampilan dasar dalam sepak bola karena semua pemain harus mampu menguasai bola saat sedang bergerak, berdiri, atau bersiap melakukan operan atau tembakan (Danny, 2007:1). Menurut Kosasih., (1994:158), menggiring bola yaitu berlari membawa bola atau membawa bola dengan kaki. Dari pendapat tersebut, kecepatan menggiring bola dapat diartikan kemampuan seseorang untuk menggunakan kakinya, mendorong bola agar bergulir terus menerus diatas tanah dengan waktu yang sesingkat singkatnya.

Untuk menggiring bola dengan baik perlu dilakukan latihan-latihan yang terus menerus sehingga akhirnya menjadi gerakan yang otomatis. Selain itu juga harus memperhatikan prinsip-prinsip menggiring bola. Prinsip-prinsip teknik menggiring bola adalah sebagai berikut : (1). Bola dalam penguasaan pemain, bola selalu dekat dengan kaki, badan pemain terletak antara bola supaya lawan tidak mudah merebut bola, bola selalu terkontrol, (2). Di depan pemain terdapat daerah yang kosong, bebas dari lawan, (3). Bola digiring dengan kaki kanan atau kaki kiri, tiap langkah kaki kanan atau kaki kiri mendorong bola kedepan, jadi bola didorong bukan ditendang. Irama sentuhan kaki pada bola tidak mengubah irama langkah kaki, (4). Pada waktu menggiring bola pandangan mata tidak boleh selalu melihat pada bola saja akan tetapi harus memperhatikan atau mengamati sekitar lapangan atau meihat posisi lawan dan kawan, dan (5). Badan condong ke depan gerakan tangan bebas seperti pada waktu lari biasa.

Berdasarkan kajian teoretis, penelitian yang relevan dan kerangka berfikir di atas, maka dapat dirumuskan hipotesis dalam penelitian ini, yakni: (1) Video pembelajaran teknik dasar bermain sepakbola menggunaan kun layak digunakan pada siswa SSB PORTIS Saentis; dan (2) Video pembelajaran teknik dasar bermain sepakbola menggunaan kun lebih efektif meningkatkan hasil latihan siswa SSB PORTIS Saentis. 


\section{METODE}

Penelitian ini dilaksanakan di lapangan sepak bola Portis Saentis, Kecamatan Percut Sei Tuan. Yang menjadi sampel dalam penelitian ini adalah siswa Sekolah Sepak Bola (SSB) Portis Saentis Kecamatan Percut Sei Tuan. Metode penelitian dan pengembangan (Research and Development) adalah metode penelitian yang digunakan untuk menghasilkan produk tertentu, dan menguji keefektifitan produk (Sugiyono, 2010: 407). Penelitian ini merupakan penelitian pengembangan yang bertujuan menghasilkan produk berupa video pembelajaran menggiring dan mengumpan bola pada teknik dasar sepakbola dengan menggunakan alat bantu berupa "kun".

Prosedur pengembangan pada video pembelajaran teknik dasar pada permainan sepakbola yaitu menggiring dan mengumpan dengan melakukan variasi pembelajaran menggunakan kun ini dilakukan melalui berbagai tahapan. Tahapan-tahapannya antara lain adalah sebagai berikut:

1. Analisis kebutuhan : kajian pustaka, observasi, dan wawancara

2. Pembuatan produk awal : tinjauan ahli pembelajaran, pendidikan jasmani, ahli perangkat lunak, dan uji coba kelompok kecil.

3. Revisi produk pertama

4. Uji coba lapangan siswa SSB Portis Saentis

5. Revisi produk akhir

6. Produk akhir pengembangan video pembelajaran teknik dasar menggiring dan mengumpan pada permainan sepak bola dengan menggunakan "kun".

Uji coba produk penelitian ini bertujuan untuk memperoleh efektivitas, efisiensi dan kebermanfaatan dari produk. Dalam penelitian ini desain yang digunakan yaitu desain eksperimental.uji coba pengembangan melalui dua tahap yaitu uji kelompok kecil dan uji coba lapangan. Jenis data dalam penelitian ini yaitu data kualitatif dan kuntitatif. Data kualitatif diperoleh dari hasil wawancara lisan maupun tulisan dari ahli pendidikan jasmani dan pakar pembelajaran sebagai bahan untuk revisi produk. Sedangkan data kuantitatif diperoleh dari kuesioner siswa. Lembar wawancara digunakan sebagai alat pengumpul data dari ahli materi sehubungan dengan saran, kritik dan masukan-masukan dari peserta didik pada saat uji coba kelompok kecil dan uji coba lapangan.

Lembar observasi dilakukan guru da peneliti secara langsung selama uji coba terhadap aktifitas belajar dan melihat respon peserta didik selama mengikuti pembelajaran dengan menggunakan paket pembelajaran.

Teknik analisis yang digunakan adalah analisis deskriptif kuantitatif. Semua data yang terkumpul diolah secara deskriptif kuantitatif dan dipisahkan menurut kategori untuk mempertajam penilaian dalam menarik kesimpulan.

\section{HASIL PENELITIAN}

Berikut ini adalah hasil analisis data yang mencakup (1) analisis data hasil validasi produk awal, (2) analisis data hasil uji coba perorangan, (3) analisis data hasil uji coba kelompok kecil dan (4) analisis data hasil uji coba lapangan terhadap video pembelajaran teknik dasar bermain sepakbola menggunakan kun pada siswa Sekolah Sepak Bola (SSB).

\section{Analisis I (Analisis Data Hasil Validasi Produk Awal)}

Hasil penilaian oleh ahli desain pembelajaran, ahli materi, dan ahli perangkat lunak pada setiap aspek penilaian secara keseluruhan ditentukan oleh skor rata-rata masing-masing aspek. Hasil penilaian tersebut kemudian dianalisis untuk menentukan layak tidaknya dikembangkan video pembelajaran teknik dasar bermain sepakbola menggunakan kun pada siswa Sekolah Sepak Bola (SSB).

Analisis Data Hasil Evaluasi Ahli Desain Pembelajaran

Tabel 1. Persentase Rata-rata Hasil Penilaian Video Pembelajaran Oleh Ahli Desain Pembelajaran

\begin{tabular}{|c|l|c|c|}
\hline No. & \multicolumn{1}{|c|}{ Aspek } & Persentase Rata-rata & Kriteria \\
\hline 1 & Aspek desain pembelajaran & $85,0 \%$ & Baik \\
\hline 2 & Aspek desain informasi & $81,6 \%$ & Baik \\
\hline 3 & Aspek desain interaksi & $80,0 \%$ & Baik \\
\hline 4 & Aspek desain presentasi & $81,6 \%$ & Baik \\
\hline & Rata-rata & $82,05 \%$ & Baik \\
\hline
\end{tabular}


Hasil penilaian oleh ahli desain pembelajaran terhadap video pembelajaran teknik dasar bermain sepakbola menggunakan kun pada siswa Sekolah Sepak Bola (SSB) dari keempat aspek pembelajaran menunjukkan persentase rata-rata $82,05 \%$ dan termasuk kategori "Baik". Untuk lebih jelas mengenai data persentase rata-rata dari ketiga aspek, dapat dilihat pada grafik berikut.

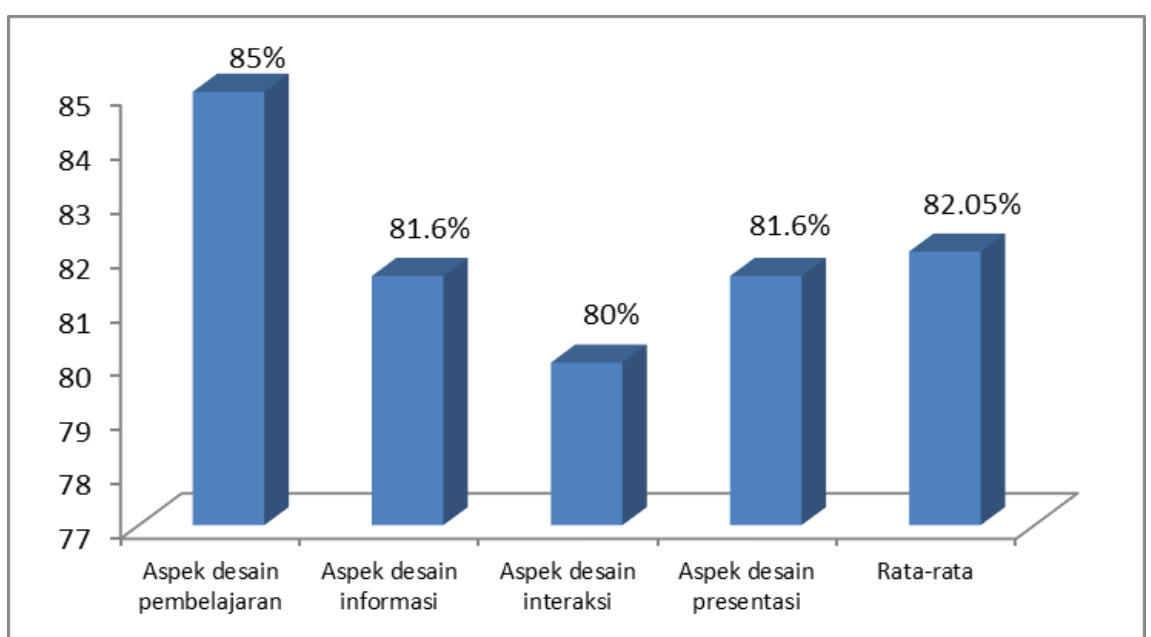

Gambar 1. Diagram Batang Skor Empiris Video Pembelajaran Teknik Dasar Bermain Sepakbola Siswa SSB Portis Saentis Percut Sei Tuan Oleh Ahli Desain Pembelajaran

Analisis Data Hasil Evaluasi Ahli Materi Pembelajaran

Tabel 2. Persentase Rata-rata Hasil Penilaian Video Pembelajaran Oleh Ahli Materi Pembelajaran

\begin{tabular}{|c|l|c|c|}
\hline No. & \multicolumn{1}{|c|}{ Aspek } & Persentase Rata-rata & Kriteria \\
\hline 1 & Aspek materi pembelajaran & $86,7 \%$ & Baik \\
\hline 2 & Aspek stgrategi informasi & $80,0 \%$ & Baik \\
\hline 3 & Aspek sistem penyampaian pembelajaran & $84,0 \%$ & Baik \\
\hline & Rata-rata & $83,6 \%$ & Baik \\
\hline
\end{tabular}

Ahli materi pembelajaran menilai video pembelajaran teknik dasar bermain sepakbola menggunakan kun pada siswa Sekolah Sepak Bola (SSB) dari ketiga aspek pembelajaran menunjukkan persentase rata-rata $83,6 \%$ dan termasuk kategori "Baik". Untuk lebih jelas mengenai data persentase rata-rata dari ketiga aspek, dapat dilihat pada grafik berikut.

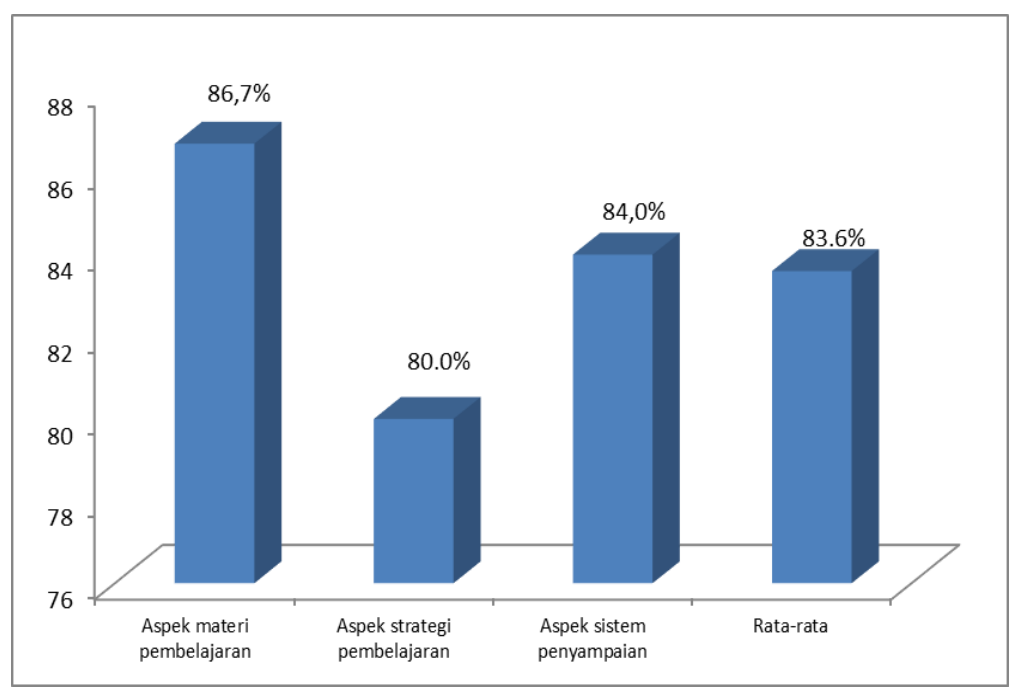

Gambar 2. Diagram Batang Skor Empiris Video Pembelajaran Teknik Dasar Bermain Sepakbola Siswa SSB Portis Saentis Percut Sei Tuan Oleh Ahli Materi Pembelajaran 
Analisis Data Hasil Evaluasi Ahli Perangkat Lunak

Tabel 3. Persentase Rata-rata Hasil Penilaian Video Pembelajaran Oleh Ahli Perangkat Lunak

\begin{tabular}{|c|l|c|c|}
\hline No. & \multicolumn{1}{|c|}{ Aspek } & Persentase Rata-rata & Kriteria \\
\hline 1 & Aspek pemrograman & $82,5 \%$ & Baik \\
\hline 2 & Aspek teknis/tampilan & $87,1 \%$ & Baik \\
\hline & Rata-rata & $84,8 \%$ & Baik \\
\hline
\end{tabular}

Ahli perangkat lunak menilai video pembelajaran teknik dasar bermain sepakbola menggunakan kun pada siswa Sekolah Sepak Bola (SSB) dari kedua aspek pembelajaran di atas, menunjukkan persentase rata-rata $84,8 \%$ dan termasuk kategori "Baik". Untuk lebih jelas mengenai data persentase rata-rata dari ketiga aspek, dapat dilihat pada grafik berikut.

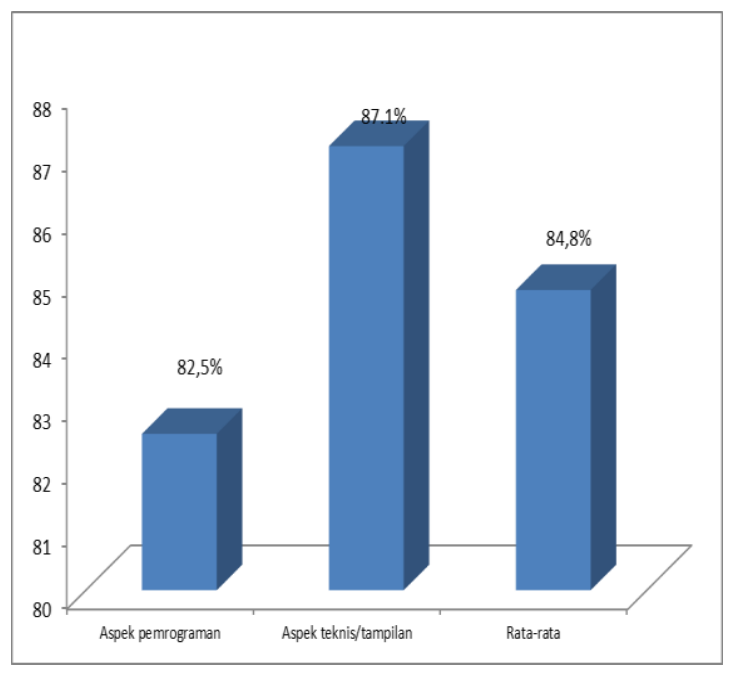

Gambar 3. Diagram Batang Skor Empiris Video Pembelajaran Teknik Dasar Bermain Sepakbola Siswa SSB Portis Saentis Percut Sei Tuan Oleh Ahli Perangkat Lunak

Berdasarkan tanggapan dan penilaian dari ahli desain pembelajaran, ahli materi pembelajaran dan ahli perangkat lunak yang telah dipaparkan di atas, maka dapat dinyatakan bahwa video pembelajaran teknik dasar bermain sepakbola menggunakan kun pada siswa Sekolah Sepak Bola (SSB) Portis Saentis Kecamatan Percut Sei Tuan Kabupaten Deli Serdang Tahun 2015 layak di uji coba lapangan dengan catatan telah direvisi sesuai catatan yang telah dikemukakan.

Hasil uji coba perorangan pada setiap aspek penilaian secara keseluruhan ditentukan oleh skor rata-rata masing-masing aspek. Hasil penilaian tersebut kemudian dianalisis untuk menentukan layak tidaknya dikembangkan video pembelajaran teknik dasar bermain sepakbola menggunakan kun pada siswa Sekolah Sepak Bola (SSB).

Tabel 4. Persentase Rata-rata Hasil Uji Coba Perorangan

\begin{tabular}{|c|l|c|c|}
\hline No. & \multicolumn{1}{|c|}{ Aspek } & Persentase Rata-rata & Kriteria \\
\hline 1 & Aspek pemrograman & $90,48 \%$ & Sangat Baik \\
\hline 2 & Aspek teknis/tampilan & $92,00 \%$ & Sangat Baik \\
\hline & Rata-rata & $91,24 \%$ & Sangat Baik \\
\hline
\end{tabular}

Hasil uji coba perorangan pada video pembelajaran teknik dasar bermain sepakbola menggunakan kun pada siswa Sekolah Sepak Bola (SSB) Portis Saentis Kecamatan Percut Sei Tuan Kabupaten Deli Serdang Tahun 2015 dari kedua aspek pembelajaran di atas, menunjukkan persentase rata-rata 91,24\% dan termasuk kategori "Sangat Baik".

Hasil uji coba kelompok kecil pada setiap aspek penilaian secara keseluruhan ditentukan oleh skor rata-rata masing-masing aspek. Hasil penilaian tersebut kemudian dianalisis untuk menentukan layak tidaknya dikembangkan video pembelajaran teknik dasar bermain sepakbola menggunakan kun pada siswa Sekolah Sepak Bola (SSB) Portis.

Tabel 5. Persentase Rata-rata Hasil Uji Coba Kelompok Kecil

\begin{tabular}{|c|l|c|c|}
\hline No. & \multicolumn{1}{|c|}{ Aspek } & Persentase Rata-rata & Kriteria \\
\hline 1 & Aspek pemrograman & $91,67 \%$ & Sangat Baik \\
\hline 2 & Aspek teknis/tampilan & $90,79 \%$ & Sangat Baik \\
\hline & Rata-rata & $91,23 \%$ & Sangat Baik \\
\hline
\end{tabular}


Hasil uji coba perorangan pada video pembelajaran teknik dasar bermain sepakbola menggunakan kun pada siswa Sekolah Sepak Bola (SSB) Portis Saentis Kecamatan Percut Sei Tuan Kabupaten Deli Serdang Tahun 2015 dari kedua aspek pembelajaran di atas, menunjukkan persentase rata-rata 91,23\% dan termasuk kategori "Sangat Baik".

Hasil uji coba lapangan pada setiap aspek penilaian secara keseluruhan ditentukan oleh skor rata-rata masing-masing aspek. Hasil penilaian tersebut kemudian dianalisis untuk menentukan layak tidaknya dikembangkan video pembelajaran teknik dasar bermain sepakbola menggunakan kun pada siswa Sekolah Sepak Bola (SSB) Portis.

Tabel 6. Persentase Rata-rata Hasil Uji Coba Lapangan

\begin{tabular}{|c|l|c|c|}
\hline No. & \multicolumn{1}{|c|}{ Aspek } & Persentase Rata-rata & Kriteria \\
\hline 1 & Aspek pemrograman & $92,27 \%$ & Sangat Baik \\
\hline 2 & Aspek teknis/tampilan & $93,84 \%$ & Sangat Baik \\
\hline & Rata-rata & $89,70 \%$ & Sangat Baik \\
\hline
\end{tabular}

Hasil uji coba perorangan pada video pembelajaran teknik dasar bermain sepakbola menggunakan kun pada siswa Sekolah Sepak Bola (SSB) Portis Saentis Kecamatan Percut Sei Tuan Kabupaten Deli Serdang dari kedua aspek pembelajaran di atas, menunjukkan persentase rata-rata 93,05\% dan termasuk kategori "Sangat Baik". Untuk lebih jelas mengenai data persentase rata-rata dari ketiga aspek, dapat dilihat pada grafik berikut.

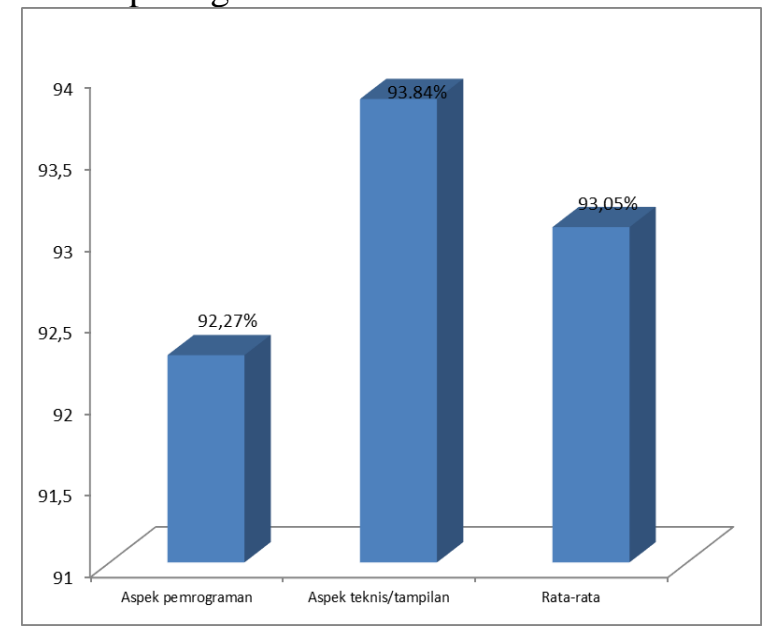

Gambar 4. Diagram Batang Skor Empiris

Video Pembelajaran Teknik

Dasar Bermain Sepakbola Siswa SSB Portis Saentis Percut Sei Tuan pada Uji Coba Lapangan

\section{Keefektifan Produk}

Hasil Latihan Sepak Bola Siswa SSB Portis Saentis Sebelum Diberikan Pembelajaran Menggunakan Media Audio Visual

Data hasil latihan siswa SSB Portis Saentis Kecamatan Percut Sei Tuan sebelum diberikan pembelajaran menggunakan media audio visual diketahui mean $=10,95$; varians $=1,97$; simpangan baku $=1,40$; skor maksimum $=13$; dan skor minimum $=7,5$. Dengan menggunakan teknik Struges didapatkan banyak kelas $=4$ dan panjang kelas 2, dan dimulai dengan ujung bawah kelas pertama yaitu 7, maka daftar distribusi frekuensi dan gambar histogram mengenai hasil latihan sepakbola siswa sebelum diberikan pembelajaran menggunakan media audio visual .

Tabel 7. Distribusi Frekuensi Skor Hasil Latihan Siswa Sebelum Diberikan Pembelajaran dengan Media Audio Visual

\begin{tabular}{|ccc|c|c|}
\hline \multicolumn{2}{|c|}{ Interval } & $\mathrm{Fi}$ & $\%$ \\
\hline 7 & - & 8 & 2 & 6.25 \\
\hline 9 & - & 10 & 9 & 28.13 \\
\hline 11 & - & 12 & 18 & 56.25 \\
\hline 13 & - & 14 & 3 & 9.38 \\
\hline Jumlah & & 32 & 100 \\
\hline
\end{tabular}

Berdasarkan tabel data diatas diperoleh sebanyak 34,38\% siswa berada di bawah ratarata, 56,25\% siswa berada di dalam rata-rata dan $9,38 \%$ berada diatas rata-rata.

\section{Hasil Latihan Sepak Bola Siswa SSB Portis Saentis Sesudah Diberikan Pembelajaran Menggunakan Media Audio Visual}

Data hasil latihan siswa SSB Portis Saentis Kecamatan Percut Sei Tuan sesudah diberikan pembelajaran menggunakan media audio visual diketahui mean $=12,55$; varians $=0,72 ;$ simpangan baku $=0,85$; skor maksimum $=13,5$; dan skor minimum $=9,5$. Dengan menggunakan teknik Struges didapatkan banyak kelas $=5$ dan panjang 
kelas 1, dan dimulai dengan ujung bawah kelas pertama yaitu 9, maka daftar distribusi frekuensi dan gambar histogram mengenai hasil latihan sepakbola siswa sesudah diberikan pembelajaran menggunakan media audio visual .

Tabel 8. Distribusi Frekuensi Skor Hasil Latihan Siswa Sesudah Diberikan Pembelajaran dengan Media Audio Visual

\begin{tabular}{|ccc|c|c|}
\hline \multicolumn{3}{|c|}{ Interval } & $\mathrm{Fi}$ & $\%$ \\
\hline 9 & - & 10 & 1 & 3.13 \\
\hline 11 & - & 12 & 10 & 31.25 \\
\hline 13 & - & 14 & 21 & 65.63 \\
\hline \multicolumn{2}{|l|}{ Jumlah } & & 32 & 100 \\
\hline
\end{tabular}

Berdasarkan tabel data di atas diperoleh sebanyak $34,38 \%$ siswa berada di bawah rata-rata, $65,63 \%$ siswa berada di dalam rata-rata dan di atas rata-rata.

Pengujian hipotesis penelitian pertama, dan kedua dilakukan dengan menggunakan rumus uji-t pada taraf signifikan $\alpha=0,05$ dengan menggunakan rumus sebagai berikut :

\section{PEMBAHASAN}

Produk pengembangan media pembelajaran dalam bentuk video pembelajaran teknik dasar menggiring dan mengumpan pada permainan sepakbola melalui pembelajaran menggunaan kun pada siswa SSB PORTIS Saentis, Kecamatan Percut Sei Tuan telah dikembangkan dengan memperhatikan aspek pembelajaran dan media sebagai prinsip desain pembelajaran.

Penelitian pengembangan produk ini diarahkan untuk menghasilkan suatu produk berupa video pembelajaran teknik dasar menggiring dan mengumpan pada permainan sepakbola yang akan digunakan untuk meningkatkan hasil latihan siswa SSB pada khususnya dan pemain sepakbola pada umumnya. Pada proses pengembangannya diawali dengan studi pendahuluan, mendesain media, melakukan validasi produk dan melakukan revisi dan penyempurnaan berdasarkan hasil analisi data validasi dari ahli desain pembelajaran, ahli materi dan ahli perangkat lunak yang dialnjutkan dengan uji coba perorangan, uji coba kelompok kecil, dan uji coba lapangan, sehingga diharapkan akan dihasilkan produk berupa video pembelajaran yang layak digunakan bagi siswa SSB sebagai pengguna/user.

$$
t_{\text {hitung }}=\frac{\bar{X}_{1}-\bar{X}_{2}}{S \sqrt{\frac{1}{n_{1}}+\frac{1}{n_{2}}}}
$$

Perhitungan uji hipotesis dapat dilihat pada lampiran 10, hasil perhitungan diperoleh nilai $t_{\text {hitung }}=5,498$

Dari tabel $\mathrm{t}$ dengan $\mathrm{db}=\mathrm{n} 1+\mathrm{n} 2-2=32+32-2$ $=62$, diperoleh nilai $\mathrm{t}_{\text {tabel }}=1,999$; sehingga diperoleh hasil nilai $t_{\text {hitung }}>t_{\text {tabel }}=5,498>$ 1,999. Dengan demikian hipotesis nol (Ho) ditolak dan hipotesis alternatif (Ha) diterima, yaitu :

1. Video pembelajaran teknik dasar menggiring dan mengumpan pada permainan sepakbola melalui pembelajaran menggunaan kun layak digunakan pada siswa SSB PORTIS"

2. Hasil latihan siswa melalui penggunaan video pembelajaran lebih efektif dibandingkan dengan hasil latihan siswa sebelum menggunakan video pembelajaran pada siswa SSB PORTIS.

Secara umum, hasil penilaian/validasi dari dari ahli desain pembelajaran, ahli materi dan ahli perangkat lunak yang dialnjutkan dengan uji coba perorangan, uji coba kelompok kecil, dan uji coba lapangan termasuk dalam kategori "Sangat baik", sehingga dapat disimpulkan bahwa penggunaan media pembelajaran ini layak digunakan bagi siswa SSB pada khususnya dan pemain sepakbola pada umumnya.

Penggunaan media pembelajaran berupa video pembelajaran pada siswa Sekolah Sepak Bola memungkinkan peserta didik untuk berinteraksi langsung dan melakukan kontrol langsung pada sumber informasi, sehingga siswa dapat mengendalikan dan memperoleh apa yang menjadi kebutuhannya.

Manfaat yang di peroleh dari penggunaan media pembelajaran berupa video pembelajaran adalah konsep yang disajikan mudah di pelajari, dipahami, dan sistematis. Media pembelajaran berupa video pembelajaran memberikan kesempatan pada peserta didik untuk belajar dan belatih sesuai dengan kecepatan masing masing, belajar lebih cepat dan tidak menimbulkan kebosanan. Hal ini didukung oleh Gerlach \& Ely (1971), yang menyatakan bahwa media secara garis besar adalah termasuk manusia, materi, atau kejadian yang membangun kondisi yang membuat siswa 
mampu memperoleh pengertahuan, keterampilan atau sikap. Secara lebih khusus, pengertian media dalam proses belajar mengajar cenderung diartikan sebagai alat-alat grafis, photogrofis, atau elektronis untuk menangkap, memproses, dan menyesun kembali informasi visual atau verbal.

Setiap jenis media pembelajaran memiliki karakteristiknya yang khas, yang dikaitkan atau dilihat dari berbagai segi (misalnya dari segi ekonomisnya, lingkup sasaran yang dapat diliput, dan kemudahan kontrolnya oleh pemakai, menurut kemampuannya membangkitkan rangsangan seluruh alat indera, dan petunjuk penggunaannya untuk mengatasi kondisi pembelajaran). Secara umum media pembelajaran memiliki tiga karakteristik atau ciri yaitu: (1). Ciri Fiksatif, yang menggambarkan kemampuan media untuk merekam, menyimpan, melestarikan, dan merekonstruksi suatu peristiwa atau obyek, (2). Ciri Manipulatif, yaitu kamampuan media untuk mentransformasi suatu obyek, kejadian atau proses dalam mengatasi masalah ruang dan waktu dan, (3). Ciri Distributif, yang menggambarkan kemampuan media mentransportasikan obyek atau kejadian melalui ruang, dan secara bersamaan kejadian itu disajikan kepada sejumlah besar siswa, di berbagai tempat, dengan stimulus pengalaman yang relatif sama mengenai kejadian tersebut.

Karakteristik media pembelajaran menjadi empat kelompok berdasarkan teknologi, yaitu: media hasil teknologi cetak, media hasil teknologi audio-visual, media hasil teknologi berdasarkan komputer, dan media hasil gabungan teknologi cetak dan komputer. Masing-masing kelompok media tersebut memiliki karakteristik yang khas dan berbeda satu dengan yang lainnya. (1). Media visual, yaitu jenis media yang digunakan hanya mengandalkan indera penglihatan peserta didik semata-mata, sehingga pengalaman belajar yang diterima peserta didik sangat tergantung pada kemampuan penglihatannya seperti buku, jurnal, poster, globe bumi, peta, foto, alam sekitar, (2). Media audio adalah jenis media yang digunakan dalam proses pembelajaran dengan hanya melibatkan indera pendengaran peserta didik. Pengalaman belajar yang akan didapatkan adalah dengan mengandalkan indera kemampuan pendengaran, (3). Media audio-visual, adalah jenis media yang digunakan dalam kegiatan pembelajaran dengan melibatkan pendengaran dan penglihatan sekaligus dalam satu proses atau kegiatan. Pesan dan informasi yang dapat disalurkan melalui media ini dapat berupa pesan verbal dan nonverbal yang mengandalkan baik penglihatan maupun pendengaran, (4). Multimedia, yaitu media yang melibatkan jenis media untuk merangsang semua indera dalam satu kegiatan pembelajaran. Multimedia lebih ditekankan pada penggunaan berbagai media berbasis TIK dan komputer.

Dari hasil pengolahan data yang dilakukan, ternyata terdapat peningkatan hasil latihan siswa SSB PORTIS Saentis, Kecamatan Percut Sei Tuan setelah mengikuti proses pembelajaran menggunakan produk pengembangan media pembelajaran dalam bentuk video pembelajaran teknik dasar menggiring dan mengumpan pada permainan sepakbola melalui pembelajaran menggunaan kun. Hal ini dapat dilihat dari nilai rata-rata hasil latihan siswa setelah mengikuti proses pembelajaran menggunakan produk pengembangan media pembelajaran dalam bentuk video pembelajaran teknik dasar menggiring dan mengumpan pada permainan sepakbola adalah 12,54 sedangkan sebelum mengikuti mengikuti proses pembelajaran menggunakan produk pengembangan media pembelajaran dalam bentuk video pembelajaran teknik dasar menggiring dan mengumpan pada permainan sepakbola nilai rata-rata hasil latihan hanya 10,95 (peningkatan sebesar 14,55\%.

Melalui pembelajaran dengan menggunakan media berupa video pembelajaran, siswa dapat berinteraksi langsung secara visual dan lebih dekat serta dapat meningkatkan minat belajar dan berlatih serta menambah motivasi siswa. Pembelajaran melalui penggunaan media berupa video pembelajaran akan dapat menambah wawasan pengetahuan serta pengalaman berlatih, karena siswa dapat mengetahui hal-hal yang lebih mendetail tentang teknik dasar menggiring dan mengumpan pada permainan sepakbola.

Berdasarkan hasil dan pembahasan di atas, dapat dicatat beberapa hal yang perlu diperhatikan dalam pelaksanaan pembelajaran. Berdasarkan temuan-temuan tersebut peneliti mengadakan penyempurnaan terhadap model pembelajaran yang dikembangkan. Kalau ada perubahan yang sangat berarti dalam video pembelajaran tersebut, maka peneliti segera mengadakan revisi agar hasil akhir lebih meningkat. Demikian dilakukan pada setiap bagian atau pokok bahasan berikutnya. Setelah beberapa putaran dilakukan dan masukan- 
masukan perbaikan kualitas video pembelajaran, maka kegiatan uji coba dihentikan. Selesai putaran uji coba terbatas para peneliti mengadakan pertemuan untuk menibahas temuan-temuan dan melakukan penyempurnaan terakhir sebelum uji coba lebih luas.

Penggunaan video sebagai sumber pembelajaran sangat penting. Dengan menggunakan video sebagai sumber pembelajaran, siswa dapat memberikan tanggapan pada video yang dikembangkan, mengomentari isi video, dan juga gerakan teknik dasar sepak bola dan juga visualisasi dari tahapan setiap gerakan. Masalah yang dibahas adalah hal-hal yang berhubungan dengan penggunaan video sebagai sumber pembelajaran sepak bola oleh siswa. Pendekatan yang digunakan dalam pembuatan video pembelajaran ini adalah pendekatan konstruktivis dan desain. Sumber pembelajaran ini adalah video yang berhubungan dengan penggunaan video sebagai sumber pembelajaran. Penggunaan video sebagai sumber pembelajaran teknik dasar sepak bola akan dapat untuk membantu siswa dalam memahami teknik dasar sepak bola yang akan dicapai dan juga dapat digunakan sebagai pemodelan pada kompetensi dasar yang lain, seperti heading dan shooting.

Dapat disimpulkan bahwa pembelajaran menggunakan produk pengembangan media pembelajaran dalam bentuk video pembelajaran teknik dasar menggiring dan mengumpan pada permainan sepakbola akan dapat meningkatkan kompetensi dan keterampilan siswa dalam bermain sepak bola.

\section{PENUTUP}

1. Video pembelajaran teknik dasar menggiring dan mengumpan pada permainan sepakbola melalui pembelajaran menggunaan kun layak digunakan pada siswa SSB PORTIS Saentis, Kecamatan Percut Sei Tuan.

2. Hasil latihan siswa melalui penggunaan video pembelajaran lebih efektif dibandingkan dengan hasil latihan siswa sebelum menggunakan video pembelajaran pada siswa SSB PORTIS Saentis, Kecamatan Percut Sei Tuan.

\section{DAFTAR PUSTAKA}

Ali M., (1987). Penelitian kependidikan prosedur dan strategi. Bandung: Offset Angka.
Aqib Zainal, (2010). Penelitian Tindakan Kelas Untuk Guru. Bandung : Yrama Widya

Arief S. 2008. Media Pendidikan. Jakarta: Raja Grafindo Persada.

Arikunto S., (2006). Prosedur Penelitian Suatu Pendekatan Praktik. Jakarta : Rineka Cipta

Arsyad, A. 2002. Media Pembelajaran, edisi 1. Jakarta: PT. Raja Grafindo Persada.

Clive G., (2003). Sepak Bola. Jakarta : Airlangga

Faruq M., (2008). Meningkatkan Kebugaran Tubuh melalui Permainan Dan Olahraga Sepakbola. Surabaya : Grasindo.

Faqih M. (2006). Persepsi Siswa Terhadap Tugas - Tugas Konselor. Skripsi tidak diterbitkan. Malang : Universitas Negeri Malang

Gerlach, Vernon S. \& Donald P. Ely. Teaching \& Media: A Systematic Approach. Second edition. (Englewood Cliffs, New Jersey: Prentice Hall, Inc., 1971

Harsono, (1988). Ilmu Coaching. Jakarta PIO. Koni Pusat.

Heri T., (2012). Pengembangan Model Pembelajaran Gosorbol Dengan Mengunakan Tangan

Husdarta dan Saputra Y., (2000). Belajar Dan Pembelajaran. Bandung: Depkiknas.

Jef S., (1988). Sepak Bola Dan Strategi Bermain. Bandung : Remaja Karya

Kosasih E.,(1994). Olahraga Pilihan. Jakarta : Depdiknas

Luxbacer J., (2011). Sepak Bola Edisi Kedua. Jakarata : Rajagrafindo.

Lutan R., dkk. (2000). Penelitian Penjaskes. Jakarta : Depdikbud.

Mahendra.(1998). Asas Dan Falsafah Pendidikan Jasmani. Bandung: FPOK UPI.

Muchtar R., (1992). Olahraga Pilihan Sepakbola. Jakarta : Depdikbud

Mielke D., (2007). Dasar-Dasar Sepak Bola. Bandung : Pakar Raya Pustaka

Richards, Jack. C. \& Ted Rodgers, (1982). "Method: Approach, Design and Procedure" dalam Tesol Quaterly, vol. 16 no. 2, Juni 1982.

Sarumpaet, (1992). Permainan Bola Besar. Jakarta : Departemen Pendidikan dan Kebudayaan.

Susilana R., dan Riyana C., (2007).Media Pembelajaran.Bandung: Wacana Prima. 
Suherman A., (2000). Dasar-dasar Penjaskes. Jakarta : Depdikbud.

Sugiyono (2010). Metode Penelitian Pendidikan,Bandung : Alfabeta.

Soekatamsi. (1984). Permainan Besar Sepak Bola 1. Jakarta : Universitas Terbuka.

Soemintro, (1992). Permainan Kecil. Jakarta : Depdikbud.

Sukintaka. (1992). Teori Bermain untuk D2 PGSD Pendidikan Jasmani.

Jakarta: Dirjen Pendidikan Tinggi Depdikbud

Sucipto. Suiyono B.,. Indra, Thohir M., Nuryadi. (2000). Sepak Bola. Jakarta : Depdikbud.
Vaughan Tai., (2004). Multimedia, Makin It Work. Edisi Keenam. Jokjakarta : Andi Ofset.

Wasis D Dwiyogo. (2008). Penelitian dan Pengembangan Olahraga. Malang : Lemlit UNM

http//:wordpress.com/2010/01/02/makalahpembelajaran-video-pembelajaran

www.google.co.id/20/5/2015

www.

indonesiajuniorsoccerleague.com/20/5/2 015 